\title{
符号化特定性原理再訪 〜信号検出理論と作動記憶理論からのアプローチ〜
}

\author{
佐々木 尚 \\ (慶應義塾大学大学院社会学研究科) \\ Key words：符号化特定性原理，信号検出理論，作動記憶
}

\section{目的}

記憶の検索手がかりの有効性を決定する要因として, 被験者がも ともと持っている知識ではなく, 学習フェーズにおける手がかり刺 激との連想関係が検索手がかりの有効性を決定するという説があ り（符号化特定性原理; Tulving \& Thomson, 1973), 最近では信号 検出理論からのアプローチが注目を浴びている (Higham, 2002； Higham \& Tam, 2005). 本研究の目的は, Higham (2002) の追試 をするとともに学習時における検索手がかりの決定における作動 記憶の役割を検討することである.

方法

被験者 都内の大学生·大学院生 20 人 $(M=22.5, S D=2.31)$.

課題 被験者は, 以下の 3 つ課題をすべて遂行した.

単語スパンテスト : 短期記憶課題として遂行された. 2 スパン条 件から 7 スパン条件までの計 6 条件あり，各条件において被験者 は 3 回遂行した. 1 秒間に 1 語の頻度でモーラ数 3 の単語が聴覚的 に提示され, 被験者はその単語を覚えるように教示された. 単語数 は 2 から 7 語であった. 単語が提示されたあと, 被験者は最初の 単語から順序良く解答用紙に記入するよう求められた。

リスニングスパンテスト : 作動記憶課題として遂行された. 2 ス パン条件から 5 スパン条件までの計 4 条件あり, 各条件において 被験者は 3 回遂行した. この課題では単文中の単語を再生させるの ではなく, 単文後に提示される単語を再生させるようにした. 単文 の内容は食物に関することとそれ以外のものとに別れており, 被験 者は聴覚提示されるこれらの文が食物に関することから゙うか内容 判断することを刺激の提示中にするように求められた. 文と単語の 提示後, 被験者は提示された単語を最初の単語から順序良く解答用 紙に記入するよう求められた。

手がかり再生課題 : Higham (2002) による課題を使った. この 課題の手がかりの提示方法は二条件あり, 符号化時に連想強度が弱 い手がかりが提示された後, 検索時にも同じ連想強度が弱い手がか りが提示される条件 (弱手がかり条件) と, 符号化時には連想強度 が弱、手がかりが提示されたあとに, 検索時には連想強度が強い手 がかりが提示される条件 (強手がかり条件) があった. また, 各条 件ともに回答の報告方法は二つあった。一つ目は自由報告条件とい い，「これらの単語を見て何か思い出せたら答えてください.もし 思い出せなかったら×と書いてください.」と教示された.さらに, Higham (2002) に従い，「回答が正しければ 1 点加算されますが, 間違っていれば 4 点減点されます」と教示された. 二つ目は強制報 告条件といい, 自由報告条件の後に被験者は「これらの単語を見て 必ず単語を記入してください.」というものであった. この条件で は, 誤答があっても減点されないことが教示された. 単語対の数は 各 24 対あり, これらはPCのスクリーンによって提示された後, 被験者は手がかり語が一ページに一語づつ書いてある冊子に回答 した.

手続き 前もって単語スパンテストとリスニングスパンテスト が遂行されたあと，手がかり再生課題が遂行された.

\section{結果}

Higham (2002) の手法を用いて，自由報告条件と強制再生条件 の検索成績を算出し，これらからヒット率と誤警報率，モニタリン グの指標として $A^{\prime}$, 報告バイアスの指標として $B_{D}{ }^{\prime \prime}$ を算出した.

検索成績 記述統計量を表 1 に示す.手がかりの連想強度と報告

\begin{tabular}{lll}
\multicolumn{3}{c}{ 表1. 検索成績 } \\
\hline & \multicolumn{1}{|}{ 自南報告 } & 強制報告 \\
\hline 弱手がかり & $0.160(0.129)$ & $0.191(0.134)$ \\
強手がかり & $0.025(0.037)$ & $0.123(0.100)$ \\
\hline 注)括弧内は標準偏差 &
\end{tabular}

方法を要因とした $2 \times 2$ の分散分析を行った結果，手がかりと報告 方法の主効果が有意であった（順に $F(1,19)=10.47, p<.005 ; F$ $(1,19)=25.67, p<.001)$. さらに，手がかり ×報告方法の交互作 用が有意であり $(F(1,19)=15.47, p<.001)$, 単純主効果の検定の 結果, 自由報告条件では手がかりの主効果は高度に有意であったが

$(F(1,19)=18.68, p<.001)$, 強制報告条件では手がかりの主効果 は有意傾向であった $(F(1,19)=4.09, p=.057)$.

ヒット率 $t$ 検定にかけたところ, 弱手がかり条件のほうが有意 に大きかった $(t(19)=7.36, p<.001$; 両側).

誤警報率 $t$ 検定にかけたところ, 弱手がかり条件のほうが有意 に大きかった $(t(19)=2.20, p<.05$; 両側).

モニタリング $A^{\prime}$ を $t$ 検定にかけたところ, 弱手がかり条件の ほうが有意に值が大きかった $(t(19)=6.74, p<.001$; 両側 $)$.

報告バイアス $B_{D}{ }^{\prime \prime}$ を $t$ 検定にかけたところ, 強手がかり条件 のほうが有意に值が大きかった $(t(19)=4.32, p<.001$; 両側 $)$.

相関分析 単語スパンテスト, リスニングスパンテストと自由報 告条件およひ強制再生条件の検索成績, ヒット率, 誤警報率, $A^{\prime}$, $B D$ "の相関係数を算出した (表 3 参照). その結果, リスニングス パンと弱手がかり条件の $A^{\prime}$ ，単語スパンと強手がかり条件の $B D D^{\prime \prime}$ の相関が $5 \%$ 水準で有意であった. 単語スパンを制御变数とし てリスニングスパンと弱手がかり条件の $A^{\prime}$ の偏相関係数を算出 したところ, $r=.59$ となり, $5 \%$ 水準で有意なままであった. また, リスニングスパンと強手がかり条件の強制再生条件の検索成績お よびヒット率との相関が有意傾向であったが, 単語スパンを制御変 数として偏相関係数を算出したところ，2つとも有意ではなくなつ た (順に $r=-.36, r=.32$ ). また，リスニングスパンと弱手がかり における $B_{D}{ }^{\prime \prime}$, 単語スパンと強手がかりにおける $B_{D}{ }^{\prime \prime}$ の相関も有 意傾向であった.

\section{考察}

手がかり再生課題の分析結果から, Higham (2002)の結果をほ ぼ再現できたことがわかった. また，単語スパンを制御変数とした リスニングスパンと弱手がかり条件の $A^{\prime}$ との偏相関係数の分析 結果から, 符号化時に対提示された弱手がかりの利用に関して作動 記憶の制御機能の成分が重要な役割を果たすことがわかった.

また本研究において, 単語スパンやリスニングスパンと報告バイ アスは相関係数は負の值をとった. この結果から, 作動記憶容量の 大きい被験者はリスキーな報告基淮を設定し, 作動記憶容量の小さ な被験者は保守的な報告基準を設定していたことが示唆される.し かし，このことは「作動記憶容量が小さいことによるメリット（齋 藤，1998)」を暗示しているのか，作動記憶容量が大きい被験者は 正答数が多くなるように報告基準を甘くするという戦略をとって いたのかわからないため, 相関係数が負の值をとった事に関しては 今後の研究でもう一度検討をする必要があるだろう.

表2. ヒット率, 誤警報率, モニタリングと反応バイアス

\begin{tabular}{lclcr}
\hline & Hit Rate & False Alarm & \multicolumn{1}{c}{$A^{\prime}$} & \multicolumn{1}{c}{$B_{D}{ }^{\prime \prime}$} \\
\hline 弱手がかり & $0.784(0.259)$ & $0.158(0.117)$ & $0.900(0.087)$ & $-0.061(0.742)$ \\
強手がかり & $0.178(0.274)$ & $0.097(0.127)$ & $0.289(0.375)$ & $0.827(0.467)$ \\
\hline
\end{tabular}

注)括弧内は標準偏差

表3. 単語スパン リスニングスパンと手がかり再生課題の各指標との相関係数

\begin{tabular}{|c|c|c|c|c|c|c|}
\hline & \multicolumn{6}{|c|}{ 弱手がかり条件 } \\
\hline & 自由報告 & 強制報告 & Hit Rate & False Alarm & $A^{\prime}$ & $B_{D}{ }^{\prime}$ \\
\hline \multirow{4}{*}{$\begin{array}{c}\text { 単語スパン } \\
\text { リスニグスパン } \\
\end{array}$} & .33 & .31 & .34 & .37 & -.05 & $-.39+$ \\
\hline & -.09 & -.23 & .32 & -.16 & $.50 *$ & -.30 \\
\hline & \multicolumn{6}{|c|}{ 強手がかり条件 } \\
\hline & 自由報告 & 強制報告 & Hit Rate & False Alarm & $A^{\prime}$ & $B_{D}$ \\
\hline 単語スパン & .14 & -.26 & .29 & .15 & .10 & $-.47 *$ \\
\hline リスニングスパン & .20 & $-.43+$ & $.41+$ & .12 & .28 & $-.38+$ \\
\hline
\end{tabular}

